\title{
Pengaruh Financial Leverage Terhadap Kinerja Keuangan (Studi Pada Perusahaan Properti dan Real Estate yang Terdaftar di Bursa Efek Indonesia Periode 2011-2015)
}

\author{
Hana Nopitasari ${ }^{1 *}$ Ermina Tiorida $^{2}$, dan Ira Siti Sarah ${ }^{3}$ \\ ${ }^{1}$ Jurusan Administrasi Niaga, Politeknik Negeri Bandung, Indonesia \\ 2 Jurusan Administrasi Niaga, Politeknik Negeri Bandung, Indonesia \\ ${ }^{3}$ Jurusan Administrasi Niaga, Politeknik Negeri Bandung, Indonesia
}

\begin{abstract}
:
The main objective of this study is to determine the effect of financial leverage on financial performance of the 39 selected property and real estate companies listed in Indonesia Stock Exchange over a periode of five years (2011-2015). This work employed two financial leverage for the independent variables such as: debt ratio $(D R)$ and debt to equity ratio $(D E R)$ in determaining their effect on financial performance such as return on equity (ROE), sales growth and price earning ratio (PER) as a dependent variables. The secondary data were obtained from the financial statement (comprehensive income statement and statement of financial position) of the selected campanies quoted from the Indonesia Stock Exchange (IDX). Descriptive statistical test, simple linear regression test and hypothesis test are used to analyze the data of this research. The results of the analysis show that there is a positive and insignificant influence between financial leverage on the financial performance of 39 companies, proven by hypothesis testing of $t$-value (1.610) $<t$-table (1.65481) and P-value of 0.109 , while the value of regression coefficient of financial performance of 0.008
\end{abstract}

Keywords: capital structure, financial leverage, financial performance

\begin{abstract}
Abstrak:
Tujuan utama penelitian ini adalah untuk mengetahui pengaruh financial leverage terhadap kinerja keuangan 39 perusahaan properti dan real estate terpilih yang terdaftar di Bursa Efek Indonesia selama lima tahun (2011-2015). Penelitian ini menggunakan dua leverage keuangan untuk variabel independen seperti debt ratio (DR) dan debt to equity ratio dalam menentukan pengaruhnya terhadap kinerja keuangan seperti return on equity (ROE), pertumbuhan penjualan dan price earning ratio (PER) sebagai variabel dependen. Data sekunder diperoleh dari laporan keuangan (laporan laba rugi komprehensif dan laporan posisi keuangan) dari perusahaan terpilih yang dikutip dari Bursa Efek Indonesia (BEI). Uji statistik deskriptif, uji regresi linier sederhana dan uji hipotesis digunakan untuk menganalisis data penelitian ini. Hasil analisis menunjukkan bahwa terdapat pengaruh positif dan signifikan antara financial leverage terhadap kinerja keuangan dari 39 perusahaan. Hal ini dibuktikan dengan pengujian hipotesis yang menghasilkan nilai t hitung $(1.610)<\mathrm{t}$-table $(1.65481)$ dan P-value sebesar 0.109, dengan nilai koefisien regresi kinerja keuangan sebesar 0,008.
\end{abstract}

Kata Kunci: struktur modal, financial leverage, kinerja keuangan

*Email korespondensi:
Hana Nopitasari
Hananovitaa@gmail.com

Jurnal Riset Bisnis \& Investasi

Vol. 3, No. 3, Desember 2017

ISSN 2460-8211

\section{PENDAHULUAN}

Pertumbuhan

perekonomian

Indonesia termasuk yang tertinggi di dunia, 
walaupun di tengah kondisi perekonomian global yang terus menurun. Pertumbuhan ekonomi Indonesia hanya kalah dari India dan China. Hal ini dibuktikan dengan kemampuan Indonesia untuk menjaga pertumbuhan ekonominya yang pada kuartal III pada tahun 2016 tumbuh sebesar 5,04\% (SindoNews.com, 2016).

Menurut Menteri Keuangan Republik Indonesia, pertumbuhan ekonomi Indonesia yang baik ini ditopang oleh pertumbuhan konsumsi sangat sehat, inflasi masih rendah $3,7 \%$ dan dari sisi investasi yang masih tumbuh mendekati 5\% (SindoNews.com, 2016). Sejalan dengan itu, Gubernur Bank Indonesia, Agus Martowardoyo juga menyatakan bahwa pertumbuhan ekonomi Indonesia pada tahun 2018 sampai 2021 akan berada dikisaran 5,9 hingga 6,3 persen, hal ini banyak disebabkan oleh inflasi yang rendah (Kompas.com, 2016).

Ini berarti pendapatan masyarakat akan terus meningkat hingga lima sampai enam tahun kedepan, mengingat diperkirakan hingga tahun 2021 pertumbuhan ekonomi Indonesia akan terus meningkat. Dengan pendapatan masyarakat yang terus meningkat tentu akan mendorong daya beli masyarakat menjadi lebih tinggi, karena mereka mampu membeli produk maupun jasa yang mereka butuhkan. Perusahaan bersaing untuk meraih pelanggan sebanyak mungkin, sehingga dapat memenuhi permintaan konsumsi masyarakat, mencapai tujuan ekspansi, menjaga kelangsungan hidup perusahaan dan yang pasti untuk mempertahankan atau meningkatkan kinerja perusahaan.

Kinerja perusahaan dapat dilihat dari berbagai sudut pandang. Salah satunya kinerja keuagnan perusahaan. Kinerja keuangan perusahaan merupakan prestasi kerja perusahaan dalam periode tertentu yang dapat dianalisis dengan alat analisis keuangan. Penilaian terhadap kinerja keuangan perusahaan adalah indikator dari baik buruknya keputusan manajemen dalam pengambilan keputusan. Penilaian atas kinerja keuangan perusahaan ini merupakan sebuah informasi yang dapat dipakai sebagai dasar pengambilan keputusan baik pihak internal maupun eksternal, khususnya penilaian kinerja perusahaan ini merupakan salah satu cara yang dapat dilakukan manajemen agar dapat memenuhi kewajibannya terhadap para penyandang dana dan juga untuk mencapai tujuan yang telah ditetapkan perusahaan.

Dalam mencapai tujuannya, perusahaan memerlukan sumber modal atau dana yang cukup. Sumber dana yang dibutuhkan perusahaan berasal dari sumber internal (internal sources) dan sumber eksternal (external sources). Dana yang berasal dari sumber internal adalah dana atau modal yang dibentuk atau dihasilkan sendiri dalam perusahaan seperti laba ditahan (retained earning), dan penyusutan (depreciation). Sementara itu, sumber eksternal (external sources) adalah sumber dana yang berasal dari luar perusahaan. Dana yang berasal dari sumber ekstern adalah dana yang berasal dari para kreditur dan pemilik, peserta atau pengambil bagian didalam perusahaan. Dana atau modal yang berasal dari para kreditur merupakan utang bagi perusahaan yang bersangkutan dan modal yang berasal dari kreditur disebut sebagai modal asing. Kebijakan dan pengambilan keputusan tentang sumber pendanaan mana yang akan dipilih tidak terlepas dari peran manajemen puncak.

Jika perusahaan memilih sumber pendanaan eksternal berupa hutang, maka penggunaan hutang itu sendiri mengandung tiga dimensi bagi perusahaan (Sartono, 2010). Pertama, pemberi kredit akan menitik beratkan pada besarnya jumlah jaminan atas kredit yang diberikan. Kedua, dengan menggunakan utang maka apabila perusahaan mendapatkan keuntungan lebih besar dari beban tetapnya maka pemilik perusahaan keuntungannya akan meningkat. Ketiga, dengan menggunakan utang pemilik memperoleh dana dan tidak kehilangan pengendalian perusahaan. Dari pernyataan 
kedua dapat disimpulkan bahwa utang akan menimbulkan beban yaitu beban bunga. Semakin besar pinjaman, semakin besar pula beban bunga yang harus dibayarkan. Biaya berupa beban bunga tersebut merupakan financial leverage.

Financial leverage ini berhubungan dengan sumber pendanaan dan dapat diukur dengan leverage ratio. Dalam penelitin ini, leverage ratio yang digunakan adalah debt ratio dan debt to equity ratio. Melalui rasiorasio tersebut akan didapatkan rasio penggunaan utang terhadap modal perusahaan, yang berdampak terhadap kinerja perusahaan.

Sementara itu untuk menilai kinerja perusahaan, akan menggunakan retun on equity, pertumbuhan penjualan dan price earning ratio. Pada umumnya, penjualan atau pendapatan digunakan untuk mengukur kinerja keuangan perusahaan. Namun pendapat itu tidak selamanya dapat dibenarkan karena masih banyak faktor lain yang harus diperhatikan sebelum menilai sejauh mana kinerja perusahaan khususnya dari segi keuangan. Maka dari itu untuk menilai kinerja perusahaan secara ideal dilakukan penilaian melalui rasio-rasio tersebut.

Penelitian ini dilakukan terhadap perusahaan sektor industri properti dan real estate yang terdaftar di Bursa Efek Indonesia tahun 2011-2015, dimana salah satu sumber pendanaan perusahaannya diperoleh dari utang. Dasar pemilihan sektor industri properti dan real estate ini adalah pertama, prospek sektor properti tahun 2017 diperkirakan lebih menjanjikan seiring dengan terus meningkatnya pertumbuhan ekonomi di Indonesia. Kedua, semakin meningkatnya kebutuhan akan properti dan real estate seiring dengan bertambahnya laju pertumbuhan penduduk tiap tahunnya, ditambah kebijakan pemerintah yang memberikan kemudahan untuk bisnis properti. Hal ini menyebabkan peningkatan permintaan akan industri properti dan real estate di Indonesia.

\section{KAJIAN LITERATUR Financial Leverage}

Arti leverage secara harfiah adalah pengungkit. Pengungkit pada dasarnya digunakan untuk membantu mengangkat beban yang berat (Piper dan Weinhold dalam Dewi, 2004), dalam hal ini leverage juga mempunyai maksud yang serupa, dimana leverage dapat digunakan untuk meningkatkan keuntungan yang diharapkan (Hanafi, 2013). Leverage merupakan penggunaan aktiva tetap atau sumber dana dimana atas penggunaan dana tersebut, perusahaan harus menanggung biaya tetap atau membayar beban tetap dengan tujuan memperbesar tingkat penghasilan bagi pemilik perusahaan. Penggunaan aktiva yang menimbulkan beban tetap disebut dengan operating leverage, sementara penggunaan dana dengan beban tetap disebut dengan financial leverage (Sudana, 2011). Dapat disimpukan bahwa finanacial leverage adalah penggunaan sumber dana dari pihak ketiga (utang) yang mana dana tersebut memiliki beban tetap yang harus dibayar perusahaan berupa bunga dengan tujuan meningkatkan struktur modal perusahaan, sehingga meningkatkan keuntungan perusahaan dan keuntungan bagi para pemegang saham. Jika perusahaan tidak mempunyai leverage, berarti perusahaan tersebut $100 \%$ menggunakan modal sendiri. Penggunaan financial leverage (utang) itu sendiri bagi perusahaan mengandung tiga dimensi (Sartono, 2001):

1. Pemberi kredit akan menitikberatkan pada besarnya jaminan atas kredit yang diberikan

2. Dengan menggunakan utang maka apabila perusahaan mendapatkan keuntungan yang lebih besar dari beban tetapnya maka pemilik perusahaan keuntungannya akan meningkat

3. Dengan menggunakan utang maka pemilik memperoleh dana dan tidak kehilangan pengendalian perusahaan.

Sejalan dengan itu Brigham dan Houston (2013) mengemukakan alasan perusahaan menggunakan financial 
leverage. Pertama, leverage mewajibkan perusahaan mengeluarkan beban tetap berupa bunga kepada para investor. Dengan adanya bunga maka pajak akan berkurang, karena bunga dapat menjadi pengurang pajak. Dengan demikian akan menyisakan laba operasi yang lebih besar bagi investor perusahaan. Kedua, jika laba operasi sebagai persentase terhadap aset melebihi tingkat bunga atas utang seperti yang umumnya diharapkan, maka perusahaan dapat menggunakan untuk membeli aset, membayar bunga atas utang dan mendapatkan sisa bonus bagi para pemegang saham.

Tingkat financial leverage dipengaruhi oleh besar bunga yang dibayarkan perusahaan, atau dengan kata lain besar utang yang digunakan perushaaan. Semakin besar utang yang digunakan perusahaan, akan semakin tinggi tingkat financial leverage nya (Fahmi, 2013). Penggunaan financial leverage pada suatu perusahaan dikatakan menguntungkan apabila pendapatan yang diterima dari penggunaan dana melalui utang tersebut mengalami peningkatan dari beban tetap penggunaan hutang tersebut (Sudana, 2011).

\section{Analisis Financial Leverage}

Dalam menganalisis financial leverage digunakan rasio yang menghitung proposi utang di dalam modal. Rasio ini disebut juga rasio leverage. Rasio leverage mengukur seberapa besar perusahaan dibiayai dengan utang (Fahmi, 2013). Dengan kata lain rasio leverage dapat dijadikan rasio untuk mengukur seberapa baik struktur permodalan perusahaan. Menurut Fahmi (2013) dibawah ini merupakan rasio yang digunakan untuk mengukur tingkat financial leverage, yaitu:

\section{Debt Ratio/ Debt to Asset Ratio}

Rasio ini mengukur berapa besar aktiva perusahaan yang dibiayai oleh kreditur atau dengan kata lain jumlah aset yang dibiayai oleh utang. Debt ratio dapat dihitung dengan membagi total utang dengan total aset (Ekwe and Duru, 2012), seperti rumus dibawah ini :

$$
D R=\frac{\text { Total Debt }}{\text { Total Assets }} \times 100 \%
$$

Sumber : Umar (2003), Sartono (2001), dan

Weston \& Copeland (2010)

2. Debt to Equity Ratio (DER)

Debt to equity ratio merupakan perbandingan antara total utang (utang lancar dan utang jangka panjang) dan modal yang menunjukkan kemampuan perusahaan untuk memenuhi kewajibannya dengan menggunakan modal yang ada. DER dihitung dengan rumus :

$$
D E R=\frac{\text { Total Utang }}{\text { Total Modal }} \times 100 \%
$$

Sumber : Umar (2003), Sartono (2001) dan Weston \& Copeland (2010)

\section{Kinerja Keuangan}

Evaluasi kinerja perusahaan dapat dilihat dalam dari berbagai sisi salah satunya dari sisi keuangan. Menurut Fahmi (2013) kinerja keuangan adalah suatu analisis yang dilakaukan untuk melihat sejauh mana suatu perusahaan telah melaksanakan aturanaturan pelaksanaan keuangan secara baik dan benar selain itu kinerja keuangan adalah gambaran kondisi keuangan perusahaan pada suatu periode tertentu baik menyangkut aspek penghimpunan dana maupun penyaluran dana, yang biasanya diukur dengan indikator kecukupan modal, likuiditas, dan profitabilitas (Jumingan, 2006) dimana hasil analisis kinerja keuangan perusahaan merupakan prestasi yang dicapai perusahaan dalam suatu periode tertentu yang mencerminkan tingkat kesehatan perusahaan tersebut (Sutrisno, 2009).

\section{Tujuan Kinerja Keuangan}

Kinerja keuangan perusahaan berkaitan erat dengan pengukuran dan penilaian kinerja. Pengukuran kinerja (performing measurement) adalah kualifikasi dan efisiensi serta efektivitas perusahaan dalam pengoperasian bisnis selama periode akuntansi. Adapun tujuan 
penilaian kinerja menurut Srimindarti (2006) adalah penentuan efektivitas operasional, organisasi, dan karyawan berdasarkan sasaran, standar dan kriteria yang telah ditetapkan sebelumnya secara periodik. Pengukuran kinerja digunakan perusahaan untuk melakukan perbaikan di atas kegiatan operasionalnya agar dapat bersaing dengan perusahaan lain. Analisis kinerja keuangan merupakan proses pengkajian secara kritis terhadap evaluasi data, menghitung, mengukur, menginterprestasi, dan memberi solusi terhadap keuangan perusahaan pada suatu periode tertentu.

Pentingnya analisis kinerja keuangan disebakan didapatnya informasi sehubungan dengan posisi keuangan dan hasil-hasil yang telah dicapai oleh perusahaan yang bersangkutan, dapat lebih berarti bagi pihakpihak yang berkepentingan (pihak internal maupun pihak eksternal) apabila hasil dari analisis kinerja keuangan diperbandingkan untuk dua periode atau lebih dan dilakukan analisis lebih lanjut sehingga dapat diperoleh data yang lebih jelas dalam mendukung keputusan yang akan diambil. Selain itu, dengan menganalisa kinerja keuangan suatu perusahaan, akan diperoleh semua jawaban yang berhubungan dengan masalah posisi keuangan dan hasil-hasil yang dicapai oleh perusahaan yang bersangkutan.

\section{Analisis Kinerja Keuangan}

Dalam mengukur kinerja keuangan perusahaan, digunakan ukuran-ukuran kinerja. Ukuran-ukuran kinerja mencerminkan keputusan-keputusan strategis, operasi dan pembiayaan. Informasi dari analisis kinerja keuangan diperlukan untuk menilai perubahan potensial sumber daya ekonomi, yang mungkin dikendalikan di masa depan dan untuk memprediksi kapasitas produksi dari sumber daya yang ada. Sedangkan laporan keuangan yang telah dianalisis sangat diperlukan pemimpin perusahaan atau manajemen untuk dijadikan sebagai alat pengambilan keputusan lebih lanjut untuk masa yang akan datang.
Evaluasi kinerja keuangan dapat dilakukan menggunakan analisis laporan keuangan. Dimana analisis laporan keuangan dapat dilakukan menggunakan rasio keuangan. Terdapat tiga ukuran kinerja keuangan perusahaan yang dianalisis dalam tiga kelompok (Weston dan Copeland, 2010):

1. Rasio Profitabilitas

Rasio profitabilitas mengukur efektifitas manajemen berdasarkan hasil pengembalian yang dihasilkan dari penjualan dan investasi. Menurut Gitman (2006) profitabilitas adalah hubungan antara pendapatan dan biaya yang dihasilkan dengan menggunakan aset perusahaan, baik saat ini maupun dalam kegiatan produktif. Dalam penelitian ini rasio profitabilitas yang digunakan adalah tingkat pengembalian atas ekuitas atau return on equity (ROE). Rasio ini mengukur hasil pengembalian nilai buku kepada pemilik perusahaan. ROE dihitung dengan cara :

$$
R O E=\frac{\text { Laba bersih }}{\text { ekuitas pemegang saham }} \times 100 \%
$$

Sumber : Sartono, 2001; Weston \& Copeland (2010)

2. Rasio Pertumbuhan

Rasio pertumbuhan mengukur kemampuan perusahaan untuk mempertahankan posisi ekonomisnya dalam pertumbuhan perekonomian dan dalam industri atau pasar produk tempatnya beroperasi. Rasio pertumbuhan dapat dilihat dari tingkat penjualan. Hal ini dipaparkan oleh Ratnawati (2007) yang menyatakan bahwa pertumbuhan perusahaan yang berkelanjutan adalah tingkat dimana penjualan perusahaan dapat tumbuh tergantung pada bagaimana dukungan asset terhadap peningkatan penjualan (Ratnawati, 2007). Perhitungan rasio pertumbuhan adalah :

Prt. penjualan $=\frac{\text { penj }_{\cdot_{t}}-\text { penj }_{\cdot_{t}-1}}{\text { penj } j_{t-1}} \times 100 \%$

Sumber : Weston \& Copeland (2010) 
3. Ukuran penilaian pasar

Ukuran penilaian mengukur kemampuan manajemen untuk mencapai nilai-nilai pasar yang melebihi pengeluaran kas dan mengukur status ekonomi perusahaan di dalam pasar. Salah satu rasio penilaian adalah pricelearning ratio ( $p / e$ ratio). Perhitungannya adalah :

PER $=\frac{\text { Harga per saham }}{\text { Laba per saham }} \times 100 \%$

Sumber : Saragih (2005), dan Weston \& Copeland (2010)

\section{Hubungan Financial Leverage Dengan Kinerja Keuangan \\ Financial leverage menunjukan} proporsi penggunaan utang untuk membiayai investasinya. Perusahaan yang tidak mempunyai leverage berarti menggunakan modal sendiri. Dengan financial leverage yang dimiliki suatu perusahaan, maka dapat disimpulkan hubungannya dengan nilai perusahaan merupakan komponen yang terkait satu sama lainnya. Nilai perusahaan dapat diketahui melalui kinerja keuangan perusahaan selama periode tertentu yang dapat dilihat dari kemampuan perusahaan memperoleh keuntungan dan tingkat pengembalian utang terhadap ekuitas dan aset. Nilai perusahaan ini dapat dilihat dari kinerja keuangan perusahaan yang diukur dari rasio-rasio keuangan.

Menurut Sartono (2011) berbagai rasio keuangan dapat dipergunakan untuk mengukur risiko dalam hubungannya dengan perusahaan yang menggunakan leverage dalam struktur modalnya. Misalnya total debt asset ratio, dan debt to equity ratio. Total debt asset ratio mengukur berapa besar aktiva perusahaan yang dibiayai oleh kreditur. Semakin rendah rasio utang maka semakin baik perusahaan tersebut, karena jika rendahnya rasio utang menandakan hanya sebagian kecil aset perusahaan uang dibiayai dengan utang. Begitu juga sebaliknya, semakin besar rasio ini berarti besar juga leverage perusahaan (Sartono, 2011). Berbeda dalam kondisi ada pajak, perusaahaan akan menjadi semakin baik apabila menggunakan utang semakin besar (Sartono, 2011) sejalan dengan itu Miller dalam Fahmi (2013) menjelaskan bahwa dalam kondisi ada pajak penghasilan, perusahaan yang memiliki leverage akan memiliki nilai lebih tinggi jika dibandingkan dengan perusahaan yang tidak memiliki leverage. Karena kenaikan nilai perusahaan terjadi ketika perusahaan membayarkan bunga atas utang, yang merupakan pengurang pajak, oleh karena itu laba operasi yang mengalir kepada investor menjadi semakin besar. Jadi, dalam penelitian ini asumsi yang digunakan adalah perusahaan akan menjadi semakin baik apabila menggunakan utang yang semakin besar. Dengan nilai utang yang semakin besar, nilai aktiva perusahaan akan mengalami penigkatan sehingga dapat membiayai segala aktivitas bisnis dengan tujuan meningkatkan profitabilitas perusahaan. Selain itu, dengan sumber dana yang lebih besar, besar kemungkinan keuntungan meningkat namun akan diikuti juga dengan peningkatan resiko (Handayani, 2014)

Rasio debt to equity ratio digunakan untuk menbandingkan sumber modal yang berasal dari utang (utang jangka panjang dan utang jangka pendek) dengan modal sendiri. Menurut (Priharyanto, 2009) bahwa semakin tinggi DER akan mempengaruhi besarnya ROI yang dicapai perusahaan. Berbeda dengan pendapat sebelumnya, Aminatuzzahra (2010) menyatakan bahwa DER secara signifikan berpengaruh terhadap ROE, dimana semakin tinggi penggunaan resiko (financial leverage) akan menghasilkan ROE yang tinggi pula. Karena dengan bertambahnya modal, profitabilitas akan meningkat pula.

Financial leverage (yang diukur melalui DR dan DER) juga berpengaruh terhadap tingkat pertumbuhan penjualan. Sebab perusahaan yang berada dalam industri yang mempunyai laju pertumbuhan penjualan yang tinggi, harus menyediakan modal yang cukup untuk membelanjai 
pengeluaran perusahaan. Perusahaan yang bertumbuh pesat cenderung lebih banyak menggunakan hutang dari pada perusahaan yang bertumbuh secara lambat. Bagi perusahaan dengan tingkat pertumbuhan penjualan dan laba yang tinggi, kecenderungan menggunakan hutang sebagai sumber dana eksternal lebih besar bila dibandingkan dengan perusahaan yang tingkat pertumbuhan penjualnnya rendah (Sartono, 2011).

Telah disebutkan sebelumnya bahawa terdapat hubungan positif antara financial leverage terhadap rasio profitabilitas dan pertumbuhan penjualan. Hal ini berarti financial leverage juga memiliki pengaruh yang sama terhadap market value perusahaan, dimana market value ratio merupakan salah satu indikator untuk mengukur kinerja keuangan perusahaan. Jika penggunaan utang dalam porsi yang tepat dapat meningkatkan profitabilitas dan pertumbuhan penjualan perusahaan, maka market value suatu perusahaan pun akan meningkat. Hal ini dikarenakan laba per saham yang ikut meningkat pula. Meningkatnya laba per lembar saham merupakan salah satu tujuan perusahaan. Dimana tujuan utama perusahaan adalah untuk meningkatkan nilai perusahaan melalui peningkatan kemakmuran pemilik atau para pemegang saham (Wahidawati, 2002). Market value yang diukur melalui $P / E$ ratio akan mencerminkan penilaian investor atas keseluruhan ekuitas yang dimiliki (Wahyudi dan Paswetri, 2006).

Oleh karena itu, hubungan antara financial leverage dengan kinerja keuangan perusahaan memiliki hubungan yang positif. Dimana DR dan DER membandingkan sumber modal yang berasal dari hutang dengan modal sendiri. Dimana perusahaan menggunakan hutang untuk menambah modal perusahaan dnegan tujuan meningkatkan keuntungan perusahaan. Dengan modal yang besar maka menimbulkan peluang untuk meningkatkan keuntungan yang besar pula (Handayani,
2014). Berdasarkan pemaparan kajian teori diatas, adapun hipotesis dalam penelitian ini adalah :

Ho : Tidak terdapat pengaruh positif dan signifikan financial leverage terhadap kinerja keuangan.

Ha : Terdapat pengaruh positif dan signifikan financial leverage terhadap kinerja keuangan.

\section{METODE PENELITIAN}

Adapun metode yang digunakan penulis dalam penelitian ini adalah metode deskriptif dan verifikatif. Menurut Sugiyono (2013:54) pengertian metode deskriptif adalah suatu metode yang berusaha menyimpulkan, menyajikan serta menganalisis data sehingga dapat memberi gambaran yang cukup jelas mengenai objek yang diteliti dan menarik kesimpulan berdasarkan penelitian yang dilakukan. Sedangkan metode verifikatif menurut Sugiyono (2013:7) adalah metode yang menguji suatu pengetahuan. Tujuan dari penelitian verifikatif ini adalah dimana penulis melakukan pengujian hipotesis yang dianalisis dengan metode statistik secara parsial dengan menggunakan uji t, selanjutnya nilai $\mathrm{t}$ hitung akan diperbandingkan dengan t tabel.

Penelitian ini menggunakan data sekunder yaitu laporan keuangan perusahaan industri properti dan real eastate di Indonesia tahun 2011-2015. Peneliti membatasi populasi yaitu perusahaan sektor properti dan real estate yang telah go public dan terdaftar di Bursa Efek Indonesia, dimana anggota yang masuk dalam populasi harus memenuhi kriteria sebagai berikut :

1. Perusahaan yang tercatat di Bursa Efek Indonesia selama tahun pengamatan (2011-2015).

2. Perusahaan yang mempublikasikan laporan keuangan selama tahun pengamatan (2011-2015), dan

3. Perusahaan tidak mengalami delisting selama tahun pengamatan (2011-2015). 
Dari kriteria yang dipaparkan, terdapat 39 perusahaan sektor industri properti dan real estate yang memenuhi kriteria tersebut.

\section{HASIL DAN PEMBAHASAN}

Analisis Deskriptif Financial Leverage

Tabel 1 merupakan hasil analisis desktiptif variabel financial leverage sesuai data yang diperoleh dari perusahaan. Tabel 1 menunjukkan bahwa financial leverage memiliki nilai mean sebesar $62,37 \%$. Jika nilai ini dibandingkan dengan Tabel 2, tingkat financial leverage industri properti dan real estate tahun 2011-2015, maka nilai mean ini termasuk dalam tingkatan yang rendah.

Tabel 1. Financial Leverage

\begin{tabular}{|l|c|c|c|c|c|}
\hline & N & Min & Max & Mean & $\begin{array}{c}\text { Std. } \\
\text { Deviation }\end{array}$ \\
\hline Financial Leverage & 156 & 6,98 & 179,44 & 62,37 & 32,935 \\
\hline Valid N & 156 & & & & \\
\hline
\end{tabular}

Tabel 2. Tingkat Financial Leverage Industri Properti dan Real Estate 2011-2015

\begin{tabular}{|c|c|}
\hline Rasio (\%) & Tingkat Financial Leverage \\
\hline $6,98-41,46$ & Sangat rendah \\
\hline $41,47-75,95$ & Rendah \\
\hline $75,96-110,44$ & Sedang \\
\hline $110,45-144,93$ & Tinggi \\
\hline $144,94-179,44$ & Sangat tinggi \\
\hline
\end{tabular}

Dimana tingkatan financial leverage pada Tabel 2 dibuat berdasarkan rentang nilai terendah hingga tertinggi dari financial leverage perusahaan properti dan real estate yang listing di BEI tahun 2011-2015 lalu dikelompokkan menjadi 5 tingkatan yang berbeda. Selain itu, Tabel 1 menunjukkan financial leverage memiliki rentang nilai minimum dan maksimum yang sangat jauh yaitu $172,46 \%$. Ada perusahaan yang nilai financial leverage nya sangat kecil, dan ada juga perusahaan yang nilai financial leverage nya sangat besar. Sejalan dengan hasil nilai minimum dan nilai maksimum yang memiliki rentang yang jauh, standar deviasi pun berada di atas $20 \%$ yaitu sebesar 52,93 . Hal ini menandakan bahwa nilai financial leverage di 39 perusahaan objek penelitian relatif berbeda. Perbedaan ini disebabkan tiap perusahaan memiliki kebijakan sendiri dalam menggunakan hutang untuk membiayai kegiatan usahanya (Fahmi, 2013). Selain itu, skala perusahaan yang berbeda-beda juga menjadi penyebab terjadinya tingkat financial leverage yang relatif berbeda pada perusahan objek penelitian. Oleh karena itu, hal yang wajar jika tingkat financial leverage di 39 perusahaan obejek penelitian ini relatif berbeda.

\section{Analisis Deskriptif Kinerja Keuangan}

Tabel 3 merupakan hasil analisis desktiptif variabel kinerja keuangan sesuai data yang diperoleh dari perusahaan. Tabel 3 menunjukkan bahwa kinerja keuangan memiliki nilai mean sebesar $21,39 \%$. Jika nilai ini dibandingkan dengan Tabel 4, tingkat kinerja keuangan industri properti dan real estate tahun 2011-2015, maka nilai mean ini termasuk dalam tingkatan yang rendah.

Tabel 3 Kinerja Keuangan

\begin{tabular}{|l|c|c|c|c|c|}
\hline & $\mathrm{N}$ & Min & Max & Mean & Std. Dev \\
\hline $\begin{array}{l}\text { Kinerja } \\
\text { Keuangan }\end{array}$ & 156 & 2,17 & 75,24 & 21,3937 & 12,6392 \\
\hline Valid N & 156 & & & & \\
\hline
\end{tabular}

Tabel 4. Tingkat Kinerja Keuangan Industri Properti dan Real Estate 2011-2015

\begin{tabular}{|c|c|}
\hline Rasio (\%) & Tingkat Kinerja Keuangan \\
\hline $2,17-16,77$ & Sangat rendah \\
\hline $16,78-31,38$ & Rendah \\
\hline $31,39-45,99$ & Sedang \\
\hline $46-60,6$ & Tinggi \\
\hline $60,61-75,24$ & Sangat tinggi \\
\hline
\end{tabular}

Sumber: Olah Data Penulis (2017)

Tingkatan kinerja keuangan pada Tabel 4 dibuat berdasarkan rentang nilai terendah hingga tertinggi dari kinerja keuangan perusahaan properti dan real estate yang listing di BEI tahun 2011-2015 lalu dikelompokkan menjadi 5 tingkatan yang berbeda. 
Dari hasil pengamatan juga terlihat bahwa kinerja keuangan memiliki nilai minimum $2,17 \%$ dan nilai maximum yang jauh diatas nilai minimum yaitu sebesar 75,24\%. Hal ini menunjukkan bahwa rentang nilai kinerja keuangan dalam 39 perusahaan yang dijadikan objek penelitian memiliki rentang yang sangat jauh. Sejalan dengan hasil nilai minimum dan nilai maksimum yang memiliki rentang yang jauh, standar deviasi pun berada di atas $20 \%$ yaitu sebesar $59,08 \%$. Hal ini menandakan bahwa nilai kinerja keuangan di 39 perusahaan objek penelitian relatif berbeda. Perbedaan ini disebabkan tiap perusahaan memiliki kemampuan dan strategi yang berbeda dalam mencapai tujuan usahanya (Riyanto, 2008). Selain itu, hal ini dikarenakan perusahaan yang dijadikan dalam objek penelitian memiliki besar ekuitas atau aktiva yang berbeda-beda tidak dalam golongan atau skala yang sama. Perusahaan dengan skala besar tentu akan menghasilkan laba yang besar pula, sementara perusahaan kecil dengan modal kecil maka laba yang dihasilkan relatif kecil (Piper dan Weinhold dalam Dewi, 2004). Dalam penelitain ini peneliti menggolongkan perusahaan ini kedalam satu sektor industri yang sama yaitu sektor properti dan real estate, artinya perusahaan dalam penelitian ini memiliki kriteria yang sama, yaitu sama-sama dalam hal kebutuhan akan pendanaan perusahaan, dimana industri properti dan real estate termasuk dalam golongan industri padat modal sementara itu jika dilihat berdasarkan kalsifikiasi industri yang ditetapkan oleh BEI yang disebut JASICA (Jakarta Stock Exchange Industrial Clasification), industri properti dan real estate termasuk dalam sektor jasa. Oleh karena itu, jika dilihat dari beberapa pernyataan di atas, hal yang wajar jika tingkat kinerja keuangan di 39 perusahaan obejek penelitian ini relatif berbeda.

\section{Hasil Analisis Korelasi}

Analisis korelasi digunakan untuk mengetahui besarnya hubungan diantara kedua variabel tersebut. Hasil analisis korelasi dari variabel inovasi dan kinerja bisnis dapat dilihat pada Tabel 5 .

Tabel 5 Hasil Analisi Korelasi

\begin{tabular}{|c|c|c|c|}
\hline & & $\begin{array}{l}\text { Financial } \\
\text { Leverage }\end{array}$ & $\begin{array}{c}\text { Kinerja } \\
\text { Keuangan }\end{array}$ \\
\hline \multirow{3}{*}{$\begin{array}{l}\text { Financial } \\
\text { Leverage }\end{array}$} & $\begin{array}{l}\text { Pearson } \\
\text { Correlation }\end{array}$ & 1 & ,129 \\
\hline & Sig. (2-tailed) & &, 109 \\
\hline & $\mathrm{N}$ & 156 & 156 \\
\hline \multirow{3}{*}{$\begin{array}{l}\text { Kinerja } \\
\text { Keuangan }\end{array}$} & $\begin{array}{l}\text { Pearson } \\
\text { Correlation }\end{array}$ &, 129 & 1 \\
\hline & Sig. (2-tailed) & , 109 & \\
\hline & $\mathrm{N}$ & 156 & 156 \\
\hline
\end{tabular}

Sumber: Olah Data SPSS (2017)

Berdasarkan Tabel 5, dapat diihat bahwa nilai korelasi antara financial leverage dengan kinerja keuangan adalah sebesar 0.129. Angka ini terdapat pada interval 0.00-0.199 yang berarti financial leverage dengan kinerja keuangan memiliki hubungan positif yang rendah. Nilai korelasi pearson pada tabel diatas menunjukkan nilai positif, maka hubungan antara financial leverage dengan kinerja bisnis adalah searah, yang berarti jika financial leverage meningkat maka akan diikuti oleh peningkatan kinerja keuangan.

\section{Hasil Analisis Regresi Linear}

Analisis regresi linear digunakan untuk memprediksi bagaimana perubahan nilai kinerja keuangan jika nilai financial leverage pada perusahaan properti dan real estate. Untuk memperoleh persamaan regresi dari penelitian mengenai pengaruh financial leverage terhadap kinerja keuangan, dapat dilihat pada Tabel 6.

Tabel 6. Hasil Analisis Regresi Linear

\begin{tabular}{|c|c|c|c|c|c|}
\hline \multirow{2}{*}{ Model } & \multicolumn{2}{|c|}{$\begin{array}{l}\text { Unstandardized } \\
\text { Coefficients }\end{array}$} & \multirow{2}{*}{\begin{tabular}{|c|}
$\begin{array}{c}\text { Standardized } \\
\text { Coefficients }\end{array}$ \\
Beta
\end{tabular}} & \multirow[t]{2}{*}{$\mathrm{t}$} & \multirow[t]{2}{*}{ Sig. } \\
\hline & B & $\begin{array}{l}\text { Std. } \\
\text { Error }\end{array}$ & & & \\
\hline (Constant) & 20,874 & 2,193 & & 9,516 &, 000 \\
\hline $1 \begin{array}{l}\text { Financial } \\
\text { Leverage }\end{array}$ & ,008 & ,031 & ,022 & 268 & ,789 \\
\hline
\end{tabular}

$$
Y=20,874+0,008 X
$$


Berdasarkan hasil persamaan regresi sederhana, nilai a dan $b$ diinterprestasikan sebagai berikut :

1. Nilai konstanta (a) sebesar 20,874 mempunyai arti bahwa jika Financial leverage $(\mathrm{X})$ terhadap pertumbuhan laba sama dengan nol $(\mathrm{x}=0)$ atau konstan, maka nilai kinerja keuangan $(\mathrm{Y})$ adalah sebesar 20,874.

2. Nilai koefisien regresi financial leverage (b) sebesar 0,008 dan bertanda positif berarti financial leverage (X) mempunyai pengaruh positif terhadap kinerja keuangan (Y), dimana jika financial leverage mengalami kenaikan sebesar satu satuan, maka kinerja keuangan mengalami kenaikan sebesar 0,008 satuan. Dapat diambil kesimpulan, bahwa jika financial leverage suatu perusahaan naik, maka kinerja perusahaan pun ikut meningkat.

\section{Hasil Koefisien Determinasi}

Koefisien determinasi digunakan untuk melihat kontribusi pengaruh yang diberikan variabel financial leverage (independen) terhadap variabel kinerja keuangan (dependen). Tabel 7 memperlihatkan hasi uji regresi linier sederhana antar variabel.

Tabel 7. Koefisien Determinasi

\begin{tabular}{|c|c|c|c|c|}
\hline Model & R & $\begin{array}{c}\text { R } \\
\text { Square }\end{array}$ & $\begin{array}{c}\text { Adjusted R } \\
\text { Square }\end{array}$ & $\begin{array}{c}\text { Std. Error of } \\
\text { the Estimate }\end{array}$ \\
\hline 1 & 0,129 & 0,017 & 0,010 & 13,53308 \\
\hline
\end{tabular}

Sumber: Olah data SPSS (2017)

Berdasarkan tabel di atas, nilai data koefisien determinasi ( $\mathrm{R}$ Square/ $\mathrm{R}^{2}$ ) adalah sebesar 0,017. Hal ini menandakan bahwa sebesar 0,017 atau $1,7 \%$ perubahan nilai kinerja keuangan dapat dijelaskan oleh variabel financial leverage. Sedangkan sisanya sebesar 98,3\% dipengaruhi oleh faktor lain yang tidak diteliti dalam penelitian ini. Rendahnya nilai $R$ square $(1,7 \%)$ menunjukkan bahwa variabel financial laverage memiliki pengaruh yang sangat rendah terhadap kinerja keuangan.

\section{Pengaruh Financial Leverage Terhadap Kinerja Keuangan}

Berdasarkan hasil uji hipotesis terhadap 156 data observasi menggunakan metode analis uji t, diperoleh hasil yang menunjukkan bahwa terdapat pengaruh positif tetapi tidak signifikan antara financial leverage terhadap kinerja keuangan perusahaan properti dan real estate yang terdaftar di BEI tahun 20112015. Hal ini sejalan dengan hasil uji determinasi $/ \mathrm{R}^{2}$ yang menunjukan nilai data koefisien determinasi ( $\mathrm{R}$ Square $/ \mathrm{R}^{2}$ ) adalah sebesar 0,017. Hal ini menandakan bahwa hanya sebesar 0,017 atau $1,7 \%$ perubahan nilai kinerja keuangan dapat dijelaskan oleh variabel financial leverage. Sedangkan sisanya sebesar 98,3\% dipengaruhi oleh faktor lain yang tidak diteliti dalam penelitian ini. Rendahnya nilai $\mathrm{R}$ square $(1,7 \%)$ menunjukkan bahwa variabel financial laverage memiliki pengaruh yang sangat rendah terhadap kinerja keuangan. Selain itu, pengujian hipotesis financial leverage terhadap kinerja keuangan menghasilkan perhitungan t-hitung $(1,610)<$ t-tabel $(1,65481)$ atau P-Value 0,109 dengan nilai koefisien regresi kinerja keuangan sebesar 0,008. Hal ini semakin membuktikan bahwa financial leverage tidak berpengaruh signifikan terhadap kinerja keuangan. Hasil ini memang berbeda dengan beberapa penelitian sebelumnya yang dilakukan oleh Handayani, dkk. (2014), Zeitun dan Tian (2007), serta Enekwe, dkk (2014) yang mengatakan bahwa terdapat pengaruh positif dan signifikan antara financial leverage terhadap kinerja keuangan. Ternyata terdapat perbedaan antara penelitian yang dilakukan sebelumnya dengan penelitian ini. Penelitian sebelumnya hanya menggunakan rasio profitabilitas sebagai indikator untuk mengukur kinerja keuangan, sementara pada penelitian ini digunakan tiga rasio keuangan yang dijadikan indikator untuk mengukur kinerja keuangan yaitu rasio profitabilitas, rasio pertumbuhan, dan penilain pasar. Alasan penulis menambahkan rasio 
pertumbuhan dan rasio ukuran penilaian adalah karena kinerja keuangan perusahaan tidak dapat diukur dari rasio profitabilitas saja (Hanafi, 2013) sejalan dengan itu Weston dan Copeland (2010) memaparkan bahwa kinerja keuangan diukur dari tiga rasio yaitu rasio profitabilitas, rasio pertumbuhan dan rasio ukuran penilaian pasar.

Pada dasarnya bahwa keuntungan perusahaan menggunakan financial leverage bergantung pada tingkat pajak yang berlaku, baik pajak untuk perusahaan maupun pajak untuk para investor, oleh karenanya menjadi sangat sulit untuk ditentukan (Piper dan Weinhold dalam Dewi, 2004). Maka dari itu, financial leverage akan mempengaruhi kinerja perusahaan yang memiliki kaitannya dengan pengurangan pajak. Seperti return on equity (ROE), dimana ROE didapatkan dari hasil pembagian antara laba bersih dengan total ekuitas. Laba bersih disini berarti total seluruh pendapatan perusahaan yang telah dikurangi oleh bunga dan pajak. Beban tetap dari penggunaan financial leverage akan mengurangi pajak perusahaan, sehingga meningkatkan penghasilan laba. Itulah sebabnya, financial leverage memiliki pengaruh terhadap ROE.

Oleh karena itu, dapat disimpulkan bahwa hasil penelitian ini menunjukkan bahwa financial leverage memiliki pengaruh positif tetapi tidak signifikan terhadap kinerja keuangan perusahaan properti dan real estate yang terdaftar di BEI selama tahun 2011-2015.

\section{KESIMPULAN DAN SARAN Kesimpulan}

1. Tingkat financial leverage perusahaan properti dan real estate yang terdaftar di BEI selama tahun 2011-2015 ada pada tingkatan yang rendah. Selain itu keadaan financial leverage persuahaan properti dan real estate dengan trend yang relatif menurun selama 5 tahun pengamatan.

2. Tingkat kinerja keuangan perusahaan properti dan real estate yang terdaftar di
BEI selama tahun 2011-2015 menunjukan tingkat kinerja yang rendah. Hal ini dapat dilihat dari tiga dimensi yang dijadikan indikator penentu kinerja keuangan yang menggambarkan kinerja keuangan perusahaan dari sudat pandang yang berbeda-beda. Secara keseluruhan kinerja keuangan perusahaan propeti dan real estate mengalami trend yang berubah-ubah setiap tahunnya.

3. Pengujian hipotesis financial leverage terhadap kinerja keuangan menghasilkan perhitungan $\mathrm{t}$-hitung $(1,610)<\mathrm{t}$-tabel $(1,65481)$ atau P-Value 0,109 dengan nilai koefisien regresi kinerja keuangan sebesar 0,008. Oleh karena itu, dapat ditarik kesimpulan bahwa financial leverage berpengaruh positif dan tidak signifikan terhadap kinerja keuangan perusahaan properti dan real estate yang terdaftar di BEI selama tahun 20112015.

\section{Saran}

Penelitan lebih lanjut untuk menganalisis pengaruh financial leverage terhadap kinerja keuangan sebaiknya dilakukan penelitian secara parsial antara indikator variabel financial leverage terhadap indikator kinerja keuangan. Sehingga dapat terlihat pengaruh yang lebih jelas antar setiap dimensinya.

\section{DAFTAR PUSTAKA}

Bappenas.go.id. (2016, 16 Agustus 2016). Mencapai Pertumbuhan Ekonomi 5,3\% serta Pengurangan TPT 5,3-5,6\% dan Tingkat Kemiskinan 9,5 - 10,5\% pada 2017. Siaran Pers. Retrieved 28 Februari, 2017, from http://www.bappenas.go.id/id/beritadan-siaran-pers/siaran-persmencapaipertumbuhan-ekonomi-53-sertapengurangan-tpt-53-56-dan-tingkatkemiskinan-95-105-pada-2017/

Dewi, I. J. (2004). Aksi teori Dalam Praktik Manajeman Keuangan. Yogyakarta: Asmara Books.

Enekwe, C. I., Ikechukwu, A. C., \& Nnagbogu, E. K. (2014). The Effect of 
Financial Leverage on Financial Performance: Evidence of Quoted Pharmaceutical Companies in Nigeria. OSR Journal of Economics and Finance (IOSR-JEF)Volume 5, Issue 3. (Sep.Oct. 2014), PP 17-25.

Fahmi, I. (2013). Analisis Laporan Keuangan, Cetakan ketiga. Bandung: Alfabeta

Gitman, J. L. (2006). Principles of Managerial Finance, eleven edition. Massachusetts: Addison-Wesley Publishing Company.

Hanafi, M. (2013). Manajemen Keuangan. Edisi Pertama.

Handayani S. R., Ludjianto, S. E., \& Hidaya, R. R. (2014). Pengaruh Analisis Leverage Terhadap Kinerja Keuangan Perushaaan. (Studi pada Perushaan Properti dan Real estate yang Listing di BEI tahun 2010-2012. Jurnal Administrasi Bisnis (JAB) 8 (1):1-8.

Kompas.com. (2016, 22 November 2016). BI Prediksi Pertumbuhan Ekonomi 2017 Sebesar 5 - 5,4 Persen. EKONOMI. Retrieved 28 Februari 2017, 2017, from http://bisniskeuangan.kompas.com/read/ 2016/11/22/205638926/bi.prediksi.pertu mbuhan.ekonomi.2017.sebesar.5.5.4.persen

Priharyanto, B. (2009). Analisis Pengaruh Current Ratio, Inventory Turnover, Debt to Equity Ratio dan Size Terhadap Profitabilitas. Tesis.Program Pasca Sarjana. Universitas Diponegoro. Semarang.

Ratnawati, T. (2007). Pengaruh Langsung dan Tidak Langsung Faktor Ekstern, Kesempatan Investasi dan Pertumbuhan Assets Terhadap Keputusan Pendanaan Perusahaan yang Terdaftar Pada Bursa Efek Jakarta (Studi pada Industri Manufaktur Masa Sebelum Krisis dan Saat Krisis). Vol. 9, No.2 (2007). The Institute of Research \& Community Outreach-Petra Christian University.
Sartono, A. (2001). Manajemen Keuangan: Teori dan Aplikasi. Edisi ke Empat. Yogyakarta: BPFE

Sartono, A. (2010). Manajemen Keuangan Teori dan Aplikasi. Edisi ke Empat, Cetakan ke Tujuh. Yogyakarta: BPFE.

SindoNews.com. (2016, Kamis, 17 November 2016 - 20:33 WIB). Pertumbuhan Ekonomi Indonesia Termasuk Tertinggi di Dunia. Ekonomi Bisnis. Retrieved 28 Februari, 2017, from

https://ekbis.sindonews.com/read/11562 11/33/sri-mulyani-pertumbuhanekonomi-indonesia-termasuk-tertinggidi-dunia-1479389615

Srimindarti, C. (2006). Balanced Scorecard Sebagai Alternatif untuk Mengukur Kinerja. Semarang: STIE Stikubank.

Sudana, I. M. (2011). Manajemen keuangan perusahaan (Teori dan Praktek). Surabaya: Erlangga

Syamsuddin, L. (2011). Manajemen Keungan Perusahaan. Jakarta : PT Rajagrafindo Persada.

Weston, J. F., \& Copeland, T. E. (2010). Manajemen Keuangan Jilid I. Terjemahan oleh Jaka Wasana. Jakarta: Binarupa

Zeitun, R., \& Tian, G. G. (2007). Capital Structure and Corporate Performance: evidence from Jordan. Australasian Accounting, Business and Finance Journal, 1(4), PP 40-61. 